\title{
Stability of Mexican Oregano Essential Oil Double Emulsions Obtained by Ultrasound Formulated With Whey Protein Concentrate and Tween 80
}

\author{
Areli H. Peredo-Luna ${ }^{1}$, Aurelio Lopez-Malo ${ }^{1}$, Enrique Palou ${ }^{1} \&$ María Teresa Jiménez-Munguía ${ }^{1}$ \\ ${ }^{1}$ School of Engineering, Department of Chemical, Environmental and Food Engineering, Universidad de las \\ Américas Puebla, Puebla, Mexico \\ Correspondence: María Teresa Jiménez-Munguía, School of Engineering, Department of Chemical, \\ Environmental and Food Engineering, Universidad de las Américas Puebla, Exhacienda Sta. Catarina Mártir S/N, \\ San Andrés Cholula Puebla, 72810, Mexico. Tel: 52-1-(222)-229-2729. E-mail: mariat.jimenez@udlap.mx
}

Received: October 27, 2016

Accepted: November 26, 2016 Online Published: December 8, 2016

doi:10.5539/jfr.v6n1p32

URL: http://dx.doi.org/10.5539/jfr.v6n1p32

\begin{abstract}
Water-in-oil-in-water $(\mathrm{W} / \mathrm{O} / \mathrm{W})$ emulsions have a great potential use for food applications because they can protect sensitive compounds, such as essential oils. The aim of this study was to determine the effect of ultrasonic homogenization parameters: intensity $(42$ or $54 \mu \mathrm{m})$ and time (5 or $7.5 \mathrm{~min})$; and formulation: oil phase proportion (20 or $30 \%$ ) and emulsifier concentration ( 0 or $0.3 \%)$; on the physical and stability properties of Mexican oregano essential oil (OEO) in double emulsions. The emulsions were made in a two-step process, primary emulsions (W/O) containing OEO in the oil phase and ascorbic acid solution in the water phase, were stabilized with lecithin; while secondary emulsions were stabilized with $6 \%(\mathrm{w} / \mathrm{w})$ of whey protein concentrate (WPC) and with or without Tween 80 (T80). Creaming, viscosity and droplet size distribution were measured to determine the stability of the $\mathrm{W} / \mathrm{O} / \mathrm{W}$ emulsions; as well as other physical properties like density and $\mathrm{pH}$. The prepared W/O/W emulsions had droplet sizes between $2.89( \pm 0.589) \mu \mathrm{m}$ and $4.123( \pm 0.964) \mu \mathrm{m}$. The most stable emulsions, with no creaming developed after 25 days of storage, were the ones formulated with WPC with T80, and additionally, $30 \%$ of the primary emulsion. Besides, higher intensity and longer time of ultrasonic homogenization conditions applied enhances W/O/W stability. Empirical models were developed for viscosity and creaming properties of $\mathrm{W} / \mathrm{O} / \mathrm{W}$ emulsions, with $99.7 \%$ of correlation coefficients, finding optimum values for specific homogenization conditions and formulation. Further studies are suggested to evaluate OEO in $\mathrm{W} / \mathrm{O} / \mathrm{W}$ emulsions as controlled release systems in food.
\end{abstract}

Keywords: double emulsions, ultrasonic homogenization, droplet size, viscosity, creaming

\section{Introduction}

Essential oils are sensitive compounds and are valuable substances because of their functional properties including, nutritional, organoleptic, antimicrobial and antioxidant properties, among others (Bakkali, Averbeck, Averbeck, \& Idaomar, 2008; Burt, 2004; Hammer, Carson, \& Riley, 1999). Nevertheless, they are susceptible to oxidative deterioration, chemical interactions and loss of volatile compounds, affecting the final quality of food in which these are added. The nano- or micro-encapsulation by means of emulsification technique has been applied to protect bioactive compounds, like essential oils; the products obtained can be used directly in the liquid state or can be dried (spray- or freeze- drying) to form powders (Bakry et al., 2016). Some important applications of microencapsulated essential oils are in beverages, meat, cheese, and fresh lettuce (Asensio, Grosso \& Juliani, 2015; Beirão da Caosta et al., 2013; Bhargava, Conti, da Rocha \& Zhang, 2015; Botsoglou, Govaris, Botsoglou, Grigoropoulou \& Papageorgiou, 2003; Lakkis, 2007).

The main problem about double emulsions is that they are highly unstable thermodynamic systems. Emulsifiers and stabilizing agents are added to achieve stable systems. The challenge in the food area is to reduce or eliminate synthetic chemical agents and replace them with safe human intake substances. In recent years, biopolymers have been investigated as emulsifiers and stabilizing agents. These biopolymers can be proteins, polysaccharides and phospholipids (Dickinson, 2011). Whey protein concentrated or isolated has been used for the aqueous phases of simple or multiple emulsions and it has been proved its efficiency at concentrations 
between 1.5\% and 15\% (Hemar, Cheng, Oliver, Sanguansri, \& Augustin, 2010; Mun et al., 2010; Surh, Vladisavljevicä, Mun, \& MCClements, 2007). Polysaccharides like gums enhance the stability of multiple emulsions due to their thickening properties. Also, stability is reached by the formation of complexes of protein-polysaccharides (Jiménez-Alvarado, Beristain, Medina-Torres, Román-Gerrero, \& Vernon-Carter, 2009; Su, Flanagan, \& Singh, 2008). In double emulsions of type water-in-oil-in-water (W/O/W) the addition of two types of emulsifiers is suggested, an emulsifier with a low HLB value is to stabilize the first emulsion water-in-oil (W/O), while an emulsifier with high HLB value can stabilize the secondary oil-in-water (O/W) emulsion. The concentration of these must be evaluated to stabilize the double emulsion $\mathrm{W} / \mathrm{O} / \mathrm{W}$ since some interactions may take place if some stabilizers are used (Jiao \& Burguess, 2003). A phospholipid that can act as an emulsifying agent is lecithin and is commonly used for food applications since it is considered as GRAS. Phosphatidylcholine-depleted lecithin has been used to stabilize W/O interphases in W/O/W double emulsions (Akhtar \& Dickinson, 2001; Knoth, Scherze, \& Muschiolik, 2005). Moreover, polyoxyethylene sorbitan esters (Tweens) have minimal toxicity and are widely used in food and pharmaceutical applications forming very stable microemulsions during storage (Jiao \& Burguess, 2003; Rukmini, Raharjo, Hastuti \& Supriyadi, 2012).

Besides the different compounds used to prepare double emulsions, the homogenization technique has also been studied to optimize the process conditions used. Among the high-energy methods used to prepare emulsions are: high pressure, microfluidization and ultrasound. With these techniques, different emulsion properties (droplet size of the disperse phase, viscosity, density, creaming) are generated according the severity of the treatment and therefore affecting their stability (Cardoso-Ugarte, López-Malo \& Jiménez-Munguía, 2016).

Since the process conditions of the homogenization for the double emulsions preparation affects the stability of the final double emulsion, as well as the use of emulsifiers and stabilizers in the formulation, an optimization of the different variables may be approached using a factorial design, in order to evaluate and compare their individual or combined effect on the stability properties of the double emulsions. Therefore, the aim of this study was to determine the effect of the ultrasonic homogenization parameters (intensity and time) and formulation (proportion of oil phase and emulsifier concentration) on the physical and stability properties of Mexican oregano essential oil in double emulsions $(\mathrm{W} / \mathrm{O} / \mathrm{W})$.

\section{Material and Methods}

Mexican oregano essential oil (OEO) (Lippia berlandieri Schauer) was provided by the Center of Research of Natural Resources (CIRENA) of Chihuahua, Mexico. OEO was mixed with corn oil (La Gloria, Mexico) to adjust the oil phase; while distilled water was used for the preparation of the aqueous phases (inner and outer). The emulsifiers and stabilizing agents were purchased as food grade: soy lecithin (Gelcaps®, Mexico), Tween 80 (sorbitan ester) (Sigma-Aldrich®, México), maltodextrin (DE 10, Globe, CPIngredientes, Mexico) and whey protein concentrate (Fleischmann, Mexico).

\subsection{Experimental Design}

A factorial design $2^{4}$ (16 experiments) was implemented for this study. Two process variables were studied, ultrasonic intensity adjusted by the wave amplitude (W) and homogenization time ( $\mathrm{min}$ ); and two more variables of formulation were varied, emulsifier concentration (T80) and the proportion of the primary emulsion (E1) used for the double emulsion preparation (E2). The different levels used for each factor are showed in Table 1.

\subsubsection{Primary Emulsion Preparation}

The primary emulsion W/O was made in a proportion of $20 / 80(\mathrm{w} / \mathrm{w})$. The inner aqueous phase was formulated with a solution of $30 \%(\mathrm{w} / \mathrm{w})$ of maltodextrin (MD) and $0.05 \%$ (total weight of emulsion, tw) of ascorbic acid; while the oil phase was a mixture of corn oil with $0.50 \%$ (tw) of Mexican OEO and $2 \%$ (tw) of lecithin. The primary emulsion was prepared with an ultrasonic homogenizer (EW-04711-70 Cole- Parmer, USA). The ultrasonic probe of 1" was introduced in a $150 \mathrm{~mL}$ tempering glass beaker, which was connected to a water bath set to $5{ }^{\circ} \mathrm{C}$. The aqueous phase was first added, submerging the probe $1 \mathrm{~cm}$ below the liquid surface. The ultrasonic intensity was adjusted to $84 \mu \mathrm{m}$ or $108 \mu \mathrm{m}$ of wave amplitude, applied during 5 or $15 \mathrm{~min}$. The dispersed phase was poured into the aqueous phase, using a syringe, when the ultrasonic homogenization process started.

\subsubsection{Secondary Emulsion Preparation}

The primary emulsion (E1) was dispersed in 70 or $80 \%$ (tw) of the outer aqueous phase $\left(\mathrm{W}_{2}\right)$ of the double emulsion. The aqueous phase was formulated with $6 \%(\mathrm{w} / \mathrm{w})$ of whey protein concentrate (WPC) and with or without $0.3 \%$ (tw) of Tween 80 (T80) as emulsifier. The ultrasound homogenization treatment was performed at $42 \mu \mathrm{m}$ or $54 \mu \mathrm{m}$ of wave amplitude, for 2.5 or $7.5 \mathrm{~min}$. 


\subsection{Emulsions Physical Properties}

The droplet size distribution of fresh prepared double emulsions, were measured using a dynamic light scattering equipment Nanotrac Wave (Microtrac, USA).

The emulsions densities were determined by the AOAC method 962.37 (1995) using Grease pycnometers, by triplicate, and was reported in $\mathrm{g} / \mathrm{cm}^{3}$.

Since the emulsions prepared were Newtonian systems, a Cannon Fenske viscometer was used to measure the dynamic viscosity of the emulsions (mPa.s); also by triplicate.

The $\mathrm{pH}$ values of the emulsions were determined using a potentiometer (Orion Research Inc., model 8005, USA), previously calibrated at $\mathrm{pH} 4$ and $\mathrm{pH}$ 7. The measurements were also done by triplicate.

Table 1. Factorial experimental design used for the double emulsions (W/OW) preparation with oregano essential oil using ultrasonic homogenization

\begin{tabular}{|c|c|c|c|c|c|c|}
\hline \multirow[b]{3}{*}{ System code } & \multicolumn{2}{|l|}{ Formulation } & \multicolumn{4}{|c|}{ Ultrasonic Homogenization } \\
\hline & \multirow[b]{2}{*}{ Stabilizer-Emulsifier } & \multirow[b]{2}{*}{ E1:E2 } & \multicolumn{2}{|r|}{ E1 } & \multicolumn{2}{|c|}{ E2 } \\
\hline & & & $\begin{array}{c}\text { Wave } \\
\text { Amplitude } \\
(\mu \mathrm{m})\end{array}$ & $\begin{array}{c}\text { Homogenization } \\
\text { time (min) }\end{array}$ & $\begin{array}{c}\text { Wave } \\
\text { Amplitude } \\
(\mu \mathrm{m})\end{array}$ & $\begin{array}{c}\text { Homogenization } \\
\text { time (min) }\end{array}$ \\
\hline A & \multirow{11}{*}{ WPC } & \multirow{5}{*}{$20: 80$} & 108 & 15 & 54 & 7.5 \\
\hline B & & & 108 & 5 & 54 & 2.5 \\
\hline $\mathrm{C}$ & & & 84 & 15 & 42 & 7.5 \\
\hline $\mathrm{D}$ & & & 84 & 5 & 42 & 2.5 \\
\hline $\mathrm{E}$ & & & 108 & 15 & 54 & 7.5 \\
\hline $\mathrm{F}$ & & \multirow{3}{*}{$30: 70$} & 108 & 5 & 54 & 2.5 \\
\hline $\mathrm{G}$ & & & 84 & 15 & 42 & 7.5 \\
\hline $\mathrm{H}$ & & & 84 & 5 & 42 & 2.5 \\
\hline I & & \multirow{4}{*}{$20: 80$} & 108 & 15 & 54 & 7.5 \\
\hline $\mathrm{J}$ & & & 108 & 5 & 54 & 2.5 \\
\hline K & & & 84 & 15 & 42 & 7.5 \\
\hline $\mathrm{L}$ & \multirow{5}{*}{ WPC-Tween 80} & & 84 & 5 & 42 & 2.5 \\
\hline M & & \multirow{4}{*}{$30: 70$} & 108 & 15 & 54 & 7.5 \\
\hline $\mathrm{N}$ & & & 108 & 5 & 54 & 2.5 \\
\hline $\mathrm{O}$ & & & 84 & 15 & 42 & 7.5 \\
\hline $\mathrm{P}$ & & & 84 & 5 & 42 & 2.5 \\
\hline
\end{tabular}

E1: Primary emulsion (W/O), E2: Secondary emulsion (W/O/W), WPC: whey protein concentrate

\subsection{Emulsions Stability}

The creaming of the double emulsions was expressed as percentage and was calculated according to equation 1 . An initial fixed volume of the double emulsion was collected in a graduated tube and the creaming phase lecture was registered as proposed by Jiao \& Burgess (2003):

$$
\text { Creaming }(\%)=100 \times\left(\mathrm{V}_{\text {total emulsion }}-\mathrm{V}_{\text {creaming }}\right) / \mathrm{V}_{\text {total emulsion }}
$$

where: $\mathrm{V}_{\text {total emulsion }}$ is the initial total double emulsion volume and $\mathrm{V}_{\text {creaming }}$ is the creaming phase volume, separated at the upper part of the emulsion. Triplicates of the measurements of $\mathrm{V}_{\text {creaming }}$ were registered every 5 days, during 25 days of storage at room temperature $\left(25^{\circ} \mathrm{C}\right)$.

\subsection{Statistical Analysis}

The emulsions physical properties were analyzed statistically, applying an ANOVA and Tukey-test to compare among the different experimental systems, using a confidence level of $95 \%$. Besides, the factorial design was also analyzed by ANOVA and two empirical models were obtained, for creaming and viscosity, as functions of the studied variables (Table 1), selecting the main variable effects and the interactions among the variables with significant effect $(\mathrm{p}<0.05)$, to include them in the model. Surface response plots were developed from these empirical models. The software used for the statistical analysis was Minitab v.17 (LEAD Technologies Inc., USA). 


\section{Results and Discussion}

\subsection{Physical Properties of W/O/W Emulsions}

It has been demonstrated that some physical properties of double emulsions are strongly related to their stability (Charoen et al., 2009; Dickinson, 2011), such as particle diameter of the dispersed phase. Small particle diameters are preferred to achieve good stability and this property is dependent of the homogenization parameters and formulation. In this study, the different systems prepared exhibited wide particle distributions; the mean diameter $\left(\mathrm{D}_{4,3}\right)$ is presented in Table 2 in order to compare the different emulsions prepared.

Table 2. Physical and physicochemical properties of double emulsions $(\mathrm{W} / \mathrm{O} / \mathrm{W})$ prepared with oregano essential oil by ultrasound

\begin{tabular}{llllc}
\hline System & Mean diameter $\left(\mathbf{D}_{\mathbf{4 , 3}}\right)(\boldsymbol{\mu m})$ & Density $\left(\mathbf{g} / \mathbf{c m}^{\mathbf{3}}\right)$ & Viscosity $(\mathbf{m P a} . \mathbf{s})$ & $\mathbf{p H}$ \\
\hline $\mathrm{A}$ & $2.82 \pm 0.07^{\mathrm{efg}}$ & $1.003 \pm 0.012^{\mathrm{a}}$ & $1.57 \pm 0.02^{\mathrm{g}}$ & $6.50 \pm 0.05^{\mathrm{a}}$ \\
$\mathrm{B}$ & $3.24 \pm 0.30^{\mathrm{de}}$ & $1.004 \pm 0.012^{\mathrm{a}}$ & $1.67 \pm 0.05^{\mathrm{f}}$ & $6.52 \pm 0.06^{\mathrm{a}}$ \\
$\mathrm{C}$ & $3.23 \pm 0.17^{\mathrm{def}}$ & $1.003 \pm 0.005^{\mathrm{a}}$ & $1.87 \pm 0.02^{\mathrm{e}}$ & $6.57 \pm 0.01^{\mathrm{a}}$ \\
$\mathrm{D}$ & $2.72 \pm 0.06^{\mathrm{fg}}$ & $1.005 \pm 0.011^{\mathrm{a}}$ & $1.57 \pm 0.03^{\mathrm{g}}$ & $6.35 \pm 0.05^{\mathrm{b}}$ \\
$\mathrm{E}$ & $4.68 \pm 0.48^{\mathrm{a}}$ & $0.992 \pm 0.029^{\mathrm{a}}$ & $3.06 \pm 0.02^{\mathrm{a}}$ & $5.56 \pm 0.01^{\mathrm{g}}$ \\
$\mathrm{F}$ & $4.23 \pm 0.42^{\mathrm{ab}}$ & $0.995 \pm 0.023^{\mathrm{a}}$ & $2.83 \pm 0.02^{\mathrm{b}}$ & $5.71 \pm 0.01^{\mathrm{f}}$ \\
$\mathrm{G}$ & $3.96 \pm 0.22^{\mathrm{bc}}$ & $0.996 \pm 0.029^{\mathrm{a}}$ & $2.53 \pm 0.02^{\mathrm{c}}$ & $5.42 \pm 0.01^{\mathrm{h}}$ \\
$\mathrm{H}$ & $4.56 \pm 0.60^{\mathrm{a}}$ & $1.009 \pm 0.021^{\mathrm{a}}$ & $2.83 \pm 0.02^{\mathrm{b}}$ & $5.52 \pm 0.03^{\mathrm{g}}$ \\
$\mathrm{I}$ & $2.28 \pm 0.18^{\mathrm{gh}}$ & $1.009 \pm 0.006^{\mathrm{a}}$ & $1.60 \pm 0.02^{\mathrm{fg}}$ & $6.11 \pm 0.03^{\mathrm{d}}$ \\
$\mathrm{J}$ & $2.24 \pm 0.11^{\mathrm{gh}}$ & $1.013 \pm 0.005^{\mathrm{a}}$ & $1.43 \pm 0.05^{\mathrm{h}}$ & $6.16 \pm 0.01^{\mathrm{cd}}$ \\
$\mathrm{K}$ & $1.94 \pm 0.11^{\mathrm{h}}$ & $1.008 \pm 0.000^{\mathrm{a}}$ & $1.63 \pm 0.02^{\mathrm{fg}}$ & $6.18 \pm 0.00^{\mathrm{c}}$ \\
$\mathrm{L}$ & $1.67 \pm 0.00^{\mathrm{i}}$ & $1.007 \pm 0.004^{\mathrm{a}}$ & $1.57 \pm 0.02^{\mathrm{g}}$ & $6.20 \pm 0.01^{\mathrm{c}}$ \\
$\mathrm{M}$ & $3.44 \pm 0.42^{\mathrm{cd}}$ & $1.008 \pm 0.044^{\mathrm{a}}$ & $2.36 \pm 0.02^{\mathrm{d}}$ & $5.85 \pm 0.01^{\mathrm{e}}$ \\
$\mathrm{N}$ & $3.06 \pm 0.10^{\mathrm{def}}$ & $0.986 \pm 0.033^{\mathrm{a}}$ & $2.55 \pm 0.02^{\mathrm{c}}$ & $5.52 \pm 0.01^{\mathrm{g}}$ \\
$\mathrm{O}$ & $2.69 \pm 0.24^{\mathrm{efg}}$ & $0.989 \pm 0.031^{\mathrm{a}}$ & $2.48 \pm 0.02^{\mathrm{c}}$ & $5.37 \pm 0.01^{\mathrm{h}}$ \\
$\mathrm{P}$ & $2.89 \pm 0.47^{\mathrm{def}}$ & $0.990 \pm 0.036^{\mathrm{a}}$ & $2.38 \pm 0.00^{\mathrm{d}}$ & $5.51 \pm 0.01^{\mathrm{g}}$ \\
\hline
\end{tabular}

Values in the same column with different letters are significantly different $(\mathrm{p}<0.05)$, analyzed by Tukey-test.

The emulsion systems from A-H were prepared with WPC, while the emulsions systems from I to $\mathrm{P}$ were prepared with WPC and the emulsifier Tween 80 (T80). Comparing these two blocks of emulsions, it was demonstrated that the addition of T80 had a significant effect on diminishing the particle size, especially for the emulsions systems I to $\mathrm{L}$ which were formulated with $20 \%$ of the primary emulsion (E1). The particle diameter of these latter systems was between 1.67 and $2.28 \mu \mathrm{m}$. In contrast, the bigger particle diameters registered were for the emulsions systems prepared with $30 \%$ of E1 and without T80 (emulsions E-H), presenting a particle diameter range between 3.96 and $4.68 \mu \mathrm{m}$. The particle size obtained of the emulsions in this research are similar to the ones reported by Jiménez-Alvarado et al. (2009), with particle size diameters around $3.85 \pm 0.04 \mu \mathrm{m}$; they also used ultrasonic homogenization for the emulsions preparation, adding WPC and arabic gum as stabilizers. Another recent study (Hernández-Marín, Lobato-Caballeros \& Vernon-Carter, 2013) of W/O/W emulsions prepared by mechanical homogenization demonstrates that complexes of whey protein and carboximethylcellulose produced stable emulsions with particle diameters in a range of 2.4-3.2 $\mu \mathrm{m}$. The droplet size range of the disperse phase of the double emulsions presented in this study suggest good stability of the emulsions since the mechanisms of coalescence may occur in a longer period of time, besides, the addition of the emulsifier increases the interfacial film strength (Jiao \& Burgess, 2003).

The $\mathrm{pH}$ value of the system is an important parameter to control emulsions separation. It has been reported that when using whey protein isolate as emulsifier, it is more effective when the emulsions are prepared at a $\mathrm{pH}$ value far from the isoelectric point of these compound, which is 5.2 (Li et al., 2011; Charoen et al., 2011; Djordjevic, Cercaci, Alamed, McClements \& Decker, 2008). The $\mathrm{pH}$ values obtained for the emulsions systems were among $5.37-6.57$ (Table 2). However, the emulsions systems $\mathrm{M}$ to $\mathrm{P}$ which had the lowest $\mathrm{pH}$ values from the rest of the prepared emulsions (5.37-5.85) were the most stables ones. It is important to recall the fact that the cavitation phenomenon, occurred during ultrasonic treatments, is able to produce molecular changes of biopolymers and molecules in general, consequently changing some of its properties and functionality (Knorr, Zenker, Heinz \& Lee, 2004; Dolatowski, Standnik \& Stasiak, 2007). 
The values obtained for the emulsions densities are between 0.986 and $1.013 \mathrm{~g} / \mathrm{cm}^{3}$ (Table 2). This is the only physical property that did not presented significant differences $(\mathrm{p}>0.05)$ among the different emulsions systems. However, the viscosity of the W/O/W emulsions was clearly affected by the addition of T80 as emulsifier. It is reported that the emulsions tend to be more stable when the viscosity increases (Jiao \& Burgess, 2003; Walstra \& van Vliet, 2008). Besides, the higher values of viscosity (2.30 - $3.06 \mathrm{mPa} . \mathrm{s})$ for the formulated double emulsions were for the systems prepared with a higher proportion of the oil phase (30\% of E1) which corresponds to the systems E-H (formulated only with WPC) and M-P (formulated with WPC and T80) (Table 2). The effect of the homogenization parameters, intensity and time of homogenization, caused significant differences in viscosity values in the emulsion systems ( $\mathrm{p}<0.05$ ), however in Table 2 is not clear to appreciate a common trend. Further on in the results of the predictive model for viscosity, trends for these process parameters will be explained.

\subsection{Creaming of W/O/W emulsions}

Generally, in W/O/W or O/W emulsions creaming occurs when the oil phase droplets in the dispersed phase are accumulated on the top of the aqueous phase. The creaming develops due to the effect of flotation or buoyancy since the oil droplets are less dense. The formation of a phase with cream like appearance is observed as a cloudy separated phase or opaque liquid (Jiao \& Burgess, 2003). In this study, it was observed that the W/O/W emulsions prepared with WPC (systems A-H, Table 1) presented creaming values up to $51.7 \%$ after 5 days of storage and increased up to $79 \%$ after 25 days of storage at room temperature (Figure 1). These creaming values are considered high, demonstrating lack of emulsions stability during storage when WPC was used as emulsifier for the double emulsions of OEO. In contrast, when WPC and T80 was added to the double emulsions formulation, with $20 \%$ of E1, homogenized with ultrasound for 15 min, after 5 days, no phase separation was observed ( $0 \%$ creaming); nevertheless, after 15 days of storage, creaming values for these emulsions was up to 76- $78 \%$ of creaming. Surh et al. (2007) reported $61 \%$ of creaming values for a $\mathrm{W}_{15 \% \mathrm{wPI}} / \mathrm{O} / \mathrm{W}$ emulsion, only after one day of storage, which was obtained after a simple pass in a high-pressure homogenizer at $7 \mathrm{MPa}$.

The most stable double emulsions systems of OEO were obtained (M-P) when WPC and T80 were used in the secondary emulsion, with $30 \%$ of E1, not mattering the ultrasound homogenization conditions applied (low or high levels of wave amplitude, for short or long time of ultrasound homogenization treatments) (Figure 1).

\subsection{Predictive models}

Among the studied physical properties of the double emulsions W/O/W with oregano essential oil, the viscosity and creaming were chosen to analyze the influence of the homogenization process parameters and the formulation variables, on these. The factorial design (Table 1) was then submitted to statistical analysis to obtain two empirical models for viscosity and creaming as the main properties mainly related to emulsions stability.

From the statistical analysis and the empirical model obtained for viscosity of the double emulsions (Table 3) it was demonstrated that all the main effects of the factors studied, homogenization wave amplitude (W), homogenization time $(\mathrm{t})$, Tween 80 concentration used (T80) and the primary emulsion concentration in the double emulsion (E1), did had a significant effect $(\mathrm{p}<0.05)$ on this property. The effect of the factors interactions are also showed in Table 3, as well as the correlation coefficient of the model for viscosity, which was $99.9 \%$. As stated before in other studies (Jiao \& Burgess, 2003; Walstra \& van Vliet, 2008; Rosa et al., 2016), as the viscosity increases, the emulsions will present better stability. As it can be seen in Figure 2, viscosity values of the double emulsions can be achieved when $\mathrm{W}$ and $\mathrm{t}$ increases (homogenization process more severe), and with higher values of E1. The effect of the addition of T80 in the W/O/W formulation is also important, however, it seems that when E1 has higher values, the viscosity is even higher for lower values of T80. The presence of $\mathrm{T} 80$ in the W/O/W becomes evidently important when creaming is analyzed after 25 days of storage.

The empirical model for the creaming property (Table 3), also presented a significant effect $(\mathrm{p}<0.05)$ of the main factors studied, as well as some factors' interactions. The coefficient correlation was also high (99.9 \%), demonstrating a good fitness of the empirical model to the data. As discussed previously, best stability of the emulsions is obtained with lower values of creaming (less phase separation); analyzing the studied factors this was obtained when $\mathrm{W}$ and $\mathrm{t}$ increases, and when E1 and T80 also are in the highest level tested. 

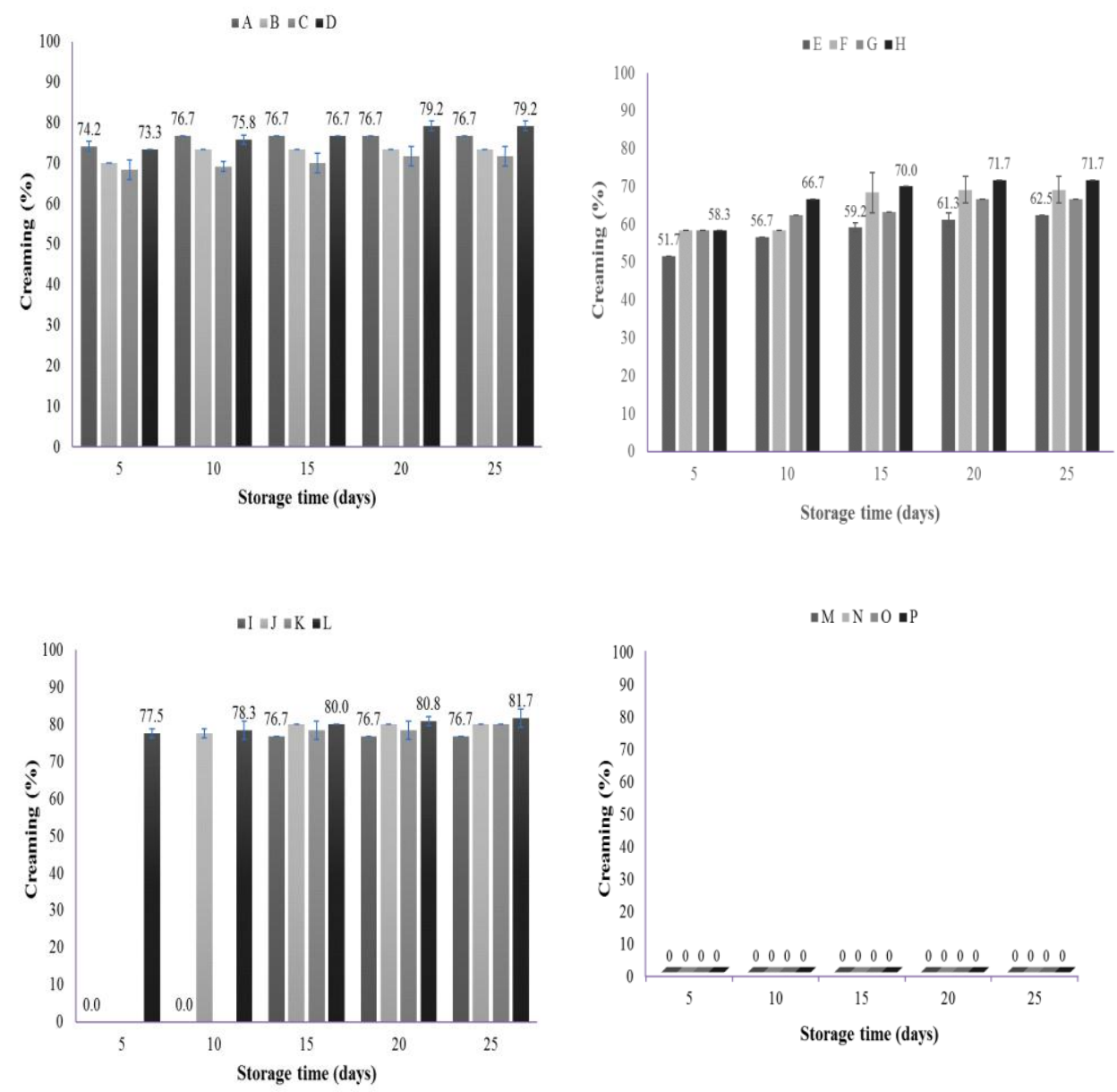

Figure 1. Creaming evolution of W/O/W emulsions prepared with oregano essential oil by ultrasound during storage. See Table 1 for emulsions systems code.

Different combinations of the factors were obtained when both empirical models (viscosity and creaming) were used to optimize the stability of the W/O/W emulsions; considering higher values for the viscosity property and lower values of creaming during storage after 25 days. The combination of the variables for the optimized response was: $54 \mu \mathrm{m}$ of $\mathrm{W}, 7.5 \mathrm{~min}$ of $\mathrm{t}, 30 \%$ of $\mathrm{E} 1$ and $0.28 \%$ of T80. With this combination of variables, the predicted value of viscosity was 2.404 mPas.s, while for creaming was $3.50 \%$ with a prediction desirability average for both empirical models of 0.753 . 
Table 3. Terms and coefficients of the models obtained for viscosity and creaming of the double emulsions prepared with oregano essential oil by ultrasonic homogenization

\begin{tabular}{lccccc}
\hline \multicolumn{1}{c}{ Term } & Units & \multicolumn{2}{c}{ Viscosity (mPa.s) } & \multicolumn{2}{c}{ Creaming (\%) } \\
\cline { 3 - 6 } & & Coefficient & p-value & Coefficient & p-value \\
\hline Constant & & -6.711 & & 207.50 & \\
Wave amplitude (W) & microns & 0.1195 & 0.000 & -2.54 & 0.003 \\
Homogenization time (t) & min & 1.8896 & 0.000 & -27.64 & 0.000 \\
Tween 80 concentration (T80) & $\%$ & 33.73 & 0.000 & 164.00 & 0.000 \\
Primary emulsion concentration (E1) & $\%$ & 0.3542 & 0.000 & -4.23 & 0.000 \\
W*t & & -0.0378 & 0.048 & 0.60 & 0.038 \\
W*T80 & & -0.673 & 0.000 & - & 0.484 \\
W*E1 & -0.0047 & 0.000 & - & 0.808 \\
t*T80 & - & 0.449 & 100.50 & 0.004 \\
t*E1 & & -0.0775 & 0.000 & - & 0.482 \\
T80*E1 & & -1.4229 & 0.000 & -14.36 & 0.000 \\
W*t*T80 & 0.1682 & 0.000 & -2.27 & 0.008 \\
W*t*E1 & 0.0015 & 0.000 & -0.03 & 0.007 \\
W*T80*E1 & & 0.0278 & 0.000 & -0.24 & 0.007 \\
t*T80*E1 & - & 0.919 & -3.37 & 0.003 \\
W*t*T80*E1 & & -0.0071 & 0.000 & 0.08 & 0.001 \\
Model concordance with data $(\%)$ & & 99.77 & & 99.70 & \\
\hline
\end{tabular}

The terms with significant effect $(\mathrm{p}<0.05)$ were included in the respective model.
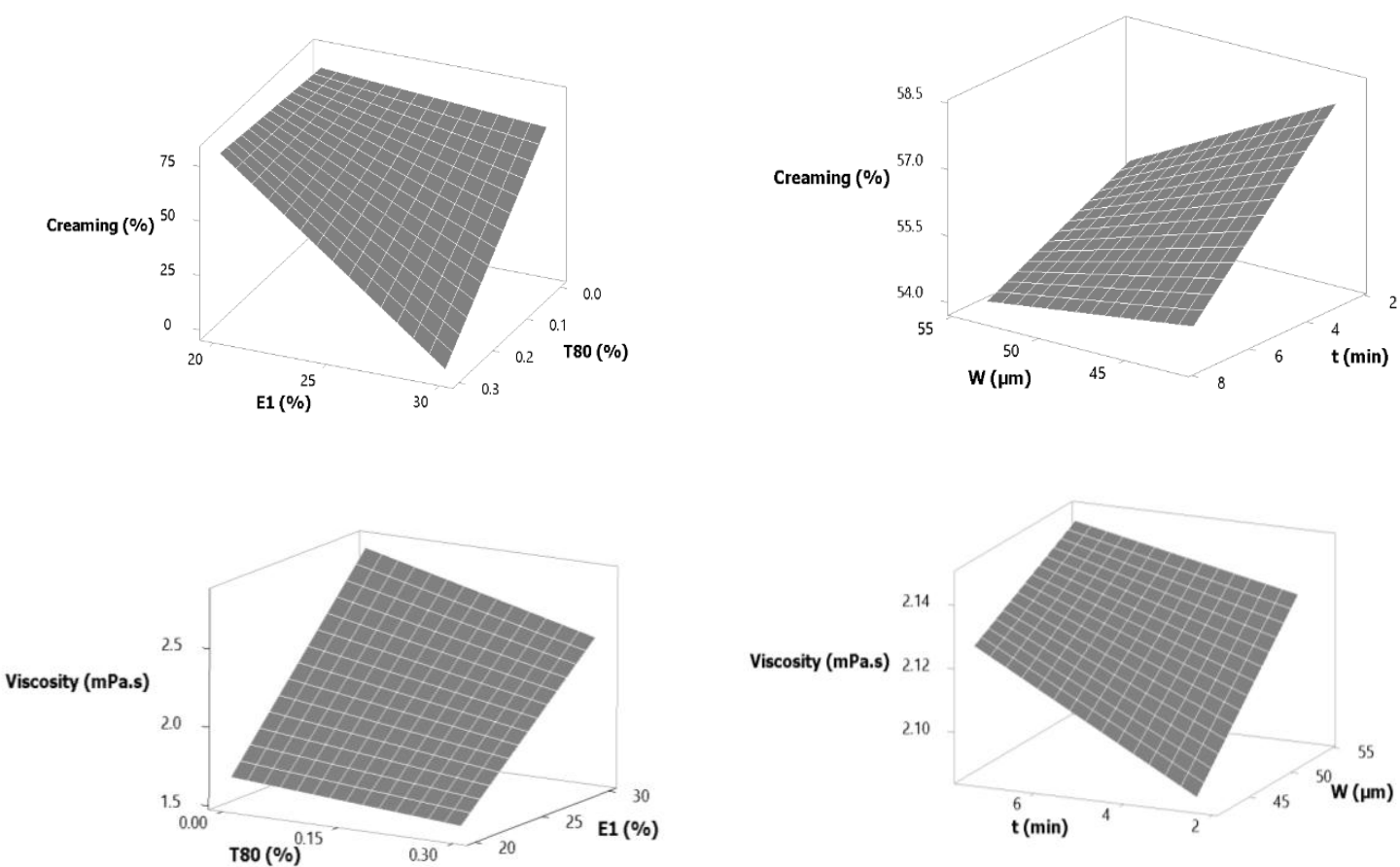

Figure 2. Surface response plots obtained for creaming and viscosity models as a function of ultrasound wave amplitude (W), homogenization time (t), Tween 80 (T80) and primary emulsion concentration (E1) for W/O/W emulsions with oregano essential oil

\section{Conclusions}

The good stability of double emulsions (W/O/W) with oregano essential oil can be achieved using whey protein concentrate (WPC) in combination with Tween 80, and adjusting the ultrasound homogenization process parameters (intensity and time). With regard to the W/O/W emulsion formulation, WPC demonstrated to be a good food-grade stabilizer since the emulsions containing it, did not showed phase separation (creaming) after 25 days of storage, when Tween 80 was also added, using a proportion 30:70 of the primary emulsion in the 
double emulsion. Moreover, good stability of the W/O/W emulsions was improved when severe ultrasonic homogenization was applied, highest wave amplitude and longer treatment times, which diminishes the particle size diameter of the dispersed phase and increases their viscosity, which are related to a better stability of the emulsions.

Two empirical models were proposed for viscosity and creaming of the W/O/W emulsions, which resulted to have high correlation coefficients to the experimental data, and included all the main effects of the variables studied and some interactions of these. A combination set of values for the different studied variables was proposed for the optimization of the emulsions stability, maximizing viscosity and minimizing creaming.

Oregano essential oil in W/O/W emulsions may be added in different types of food, in which their antimicrobial or antioxidant properties may be exploited, since these emulsions may serve as controlled release systems.

\section{Acknowledgments}

The authors acknowledge the financial support of the National Council of Science and Technology (CONACYT) of Mexico, for the project 168709 CB-2011-01. Author Peredo-Luna gratefully acknowledges the financial support for her PhD studies to CONACyT and the Universidad de las Américas Puebla (UDLAP).

\section{References}

A.O.A.C. Official Methods of Analysis (1995). $14^{\text {th }}$ ed. Association of Official Analytical Chemists. Inc. Washington, D.C. USA.

Akhtar, M., \& Dickinson, E. (2001). Water-in-oil-in-water multiple emulsions stabilized by polymeric and natural emulsifiers. In E. Dickinson, R. Miller (eds), Food Colloids: Fundamentals of Formulation (pp 133 - 143). Cambridge, UK: Royal Society of Chemistry.

Asensio, C. M., Grosso, N. R., \& Juliani, H. R. (2015). Quality preservation of organic cottage cheese using oregano essential oils. LWT-Food Science and Technology, 60(2), 664-671. http://dx.doi.org/10.1016/j.1wt.2014.10.054

Bakkali, F., Averbeck, S., Averbeck, D., \& Idaomar, M. (2008). Biological effects of essential oils-A review. Food and Chemical Toxicology, 46(2), 446-475. http://dx.doi.org/10.1016/j.fct.2007.09.106

Bakry, A. M., Abbas, S., Ali, B., Majeed, H., Abouelwafa, M. Y., Mousa, A., \& Liang, L. (2016). Microencapsulation of oils: a comprehensive review of benefits, techniques, and applications. Comprehensive Reviews in Food Science and Food Safety, 15(1), 143-182. http://dx.doi.org/10.1111/1541-4337.12179

Beirão-da-Costa, S., Duarte, C., Bourbon, A. I., Pinheiro, A. C., Januário, M. I. N., Vicente, A. A., Beirão, da Costa, M. L., \& Delgadillo, I. (2013). Inulin potential for encapsulaton and controlled delivery of Oregno essential oil. Food Hydrocolloids, 33, 199-206. http://dx.doi.org/10.1016/j.foodhyd.2013.03.009

Bhargava, K., Conti, D. S., da Rocha, S. R. P., \& Zhang, Y. F. (2015). Application of an oregano oil nanoemulsion to the control of foodborne bacteria on fresh lettuce. Food Microbiology, 47, 69-73. http://dx.doi.org/10.1016/j.fm.2014.11.007

Bostsoglou, N. A., Govaris, A., Botsoglou, E. N., Grigoropoulou, S. H., \& Papageorgiou, G. (2003). Antioxidant activity of dietary oregano essential oil and alpha-tocopheryl acetate supplementation in logn-term frozen stored turkey meat. Journal of Agricultural and Food Chemistry, 51(10), 2930-2936. http://dx.doi.org/10.1021/jf021034o

Burt, S. (2004). Essential oils: their antibacterial properties and potential applications in foods-a review. International Journal of Food Microbiology, 94, 223-253. http://dx.doi.org/10.1016/j.ijfoodmicro.2004.03.022

Cardoso-Ugarte, G. A., López-Malo, A., \& Jiménez-Munguía, M. T. (2016). Application of nanoemulsions technology for encapsulation and release of lipohilic bioactive compounds in food. In Grumezescu, A. (ed.), Emulsions (pp 227-255), Elsevier. ISBN: 978-0-12-804306-6.

Charoen, R., Jangchud, A., Jangchud, K., Harnsilawat, T., Naivikul, O., \& David Julian McClements, D.J. (2011). Influence of biopolymer emulsifier type on formation and stability of rice bran oil-in-water emulsions: whey protein, gum arabic, and modified starch. Journal of Food Science, 76(1), E165-E172. http://dx.doi.org/10.1111/j.1750-3841.2010.01959.x

Dickinson, E. (2011). Double emulsions stabilized by food biopolimers. Food Biophysics, 6, 1-11. http://dx.doi.org/10.1007/s11483-010-9188-6 
Djordjevic, D., Cercaci, L., Alamed, J., McClements, D., \& Decker, E. A. (2008). Chemical and phisical stabilityof protein- and gum arabic-stabilized oil -in-water emulsions containing Limonene. Journal of Food Science, 73(3), C167-C172. http://dx.doi.org/10.1111/j.1750-3841.2007.00659.x

Dolatowski, Z. J., Standnik, J., \& Stasiak, D. (2007). Applications of ultrasound in food technology. Acta Scientiarum Polonorium Technologia Alimentaria, 6(3), 89-99.

Hammer, K. A., Carson, C. F., \& Riley, T. V. (1999). Antimicrobial activity of essential oils and other plant extracts. Journal of Applied Microbiology, 86, 985-990. http://dx.doi.org/10.1046/j.1365-2672.1999.00780.x

Hemar, Y., Cheng, L. J., Oliver, C. M., Sanguansri, L., \& Augustin, M. (2010). Encapsulation of resveratrol using water-in-oil-in-water double emulsions. Food Biophysics, 5, 120-127. http://dx.doi.org/10.1007/s11483-010-9152-5

Hernández-Marín, N. Y., Lobato-Calleros, C., \& Vernon-Carter, E. J. (2013). Stability and rheology of water-in-oil-in-water emulsions made with protein-polysaccharide soluble complexes. Journal of Food Engineering, 119, 181-187. http://dx.doi.org/10.1016/j.jfoodeng.2013.05.039

Jiao, J., \& Burgess, D. J. (2003). Rheology and stability on water-in-oil-in-water emulsions containing Span 83 and Tween 80. AAPS Pharmaceutical Science, 5(1), E7-E19. http://dx.doi.org/10.1208/ps050107

Jiménez-Alvarado, R., Beristain, C. I., Medina-Torres, L., Román-Gerrero, A., \& Vernon-Carter, E. J. (2009). Ferreus bisglycinate and release in $\mathrm{w} 1 / \mathrm{o} / \mathrm{w} 2$ multiple emulsions stabilized by protein-polysaccharide complexes. Food Hydrocolloids, 23, 2425-2433. http://dx.doi.org/10.1016/j.foodhyd.2009.06.022

Knorr D., Zenker, M., Heinz, V., \& Lee, D. U. (2004). Applications and potential of ultrasonics in food processing. Trends in Food Science and Technology, 15, 261-266. http://dx.doi.org/10.1016/j.tifs.2003.12.001

Knoth, A., Scherze, I., \& Muschiolik, G. (2005.) Stability of water-in-oil-emulsions containing phosphatidylcholine-depleted lecithin. Food Hydrocolloids, 19, 635-640. http://dx.doi.org/10.1016/j.foodhyd.2004.10.024

Li, B., Jiang, Y., Liu, F., Chai, Z., Li, Y., \& Leng, X. (2011). Study of the encapsulation efficiency and controlled release property of whey protein isolate-polysaccharide complexes in $\mathrm{W} 1 / \mathrm{O} / \mathrm{W} 2$ double emulsions. International Journal of Food Engineering, 7(3), Art. 14. http://dx.doi.org/10.2202/1556-3758.2321

Mun, S., Choi, Y., Rho, S. J., Kang, C. G., Park, C. H., \& Kim, Y. R. (2010). Preparation and characterization of water/oil/water emulsions stabilized by polyglycerol polyricinoleate and whey protein isolate. Journal of Food Science, 75, E116-E125. http://dx.doi.org/10.1111/j.1750-3841.2009.01487.x

Rosa, T. M. M. G., Silva, E. K., Santos, D. T., Petenate, A. J., Angela, M., \& Meireles, A. (2016). Obtaining annatto seed oil miniemulsions by ultrasonication using aqueous extract from Brazilian gingseng roots as a biosurfactant. Journal of Food Engineering, 168, 68-78. http://dx.doi.org/10.1016/j.jfoodeng.2015.07.024

Rukmini, A., Raharjo, S., Hastuti, P., \& Supriyadi, S. (2012). Formulation and stability of wáter-in-virgin coconut oil microemulsion using ternary food grade nonionic surfactants. International Food Research Journal, 19(1), 259-264.

$\mathrm{Su}$, J., Flanagan, J., \& Singh, H. (2008). Improving encapsulation efficiency and stability of water-in-oil-in-water emulsions using a modified gum arabic (Acacia (sen) SUPER GUMTM). Food Hydrocolloids, 22, 112-120. http://dx.doi.org/10.1016/j.foodhyd.2007.03.005

Surh, J., Vladisavljevicä, G. T., Mun, S., \& McClements, D. J. (2007). Preparation and characterization of water/oil and water/oil/ water emulsions containing biopolymer-gelled water droplets. Journal of Agricultural and Food Chemistry, 55, 175-184. http://dx.doi.org/10.1021/jf061637q

Walstra, P., \& van Vliet, T. (2008). Dispersed systems: basic considerations. In S. Damodaran, K. Parking, \& O. R. Fennema (Eds.), Fenema's food chemistry (pp. 783-847). Boca Raton: CRCPress/Taylor\&Fracis.

\section{Copyrights}

Copyright for this article is retained by the author(s), with first publication rights granted to the journal.

This is an open-access article distributed under the terms and conditions of the Creative Commons Attribution license (http://creativecommons.org/licenses/by/4.0/). 